\title{
Artelogie
}

Recherche sur les arts, le patrimoine et la littérature de l'Amérique latine

\section{Imagen, texto y artefacto. La fotografía etnográfica del Gran Chaco argentino en publicaciones impresas contemporáneas}

\section{Alejandra Reyero}

\section{(2) OpenEdition}

\section{Journals}

Edición electrónica

URL: https://journals.openedition.org/artelogie/1139

DOI: 10.4000/artelogie.1139

ISSN: 2115-6395

Editor

Association ESCAL

Referencia electrónica

Alejandra Reyero, «Imagen, texto y artefacto. La fotografía etnográfica del Gran Chaco argentino en publicaciones impresas contemporáneas», Artelogie [En línea], 7| 2015, Publicado el 15 abril 2015, consultado el 11 abril 2022. URL: http://journals.openedition.org/artelogie/1139 ; DOI: https://doi.org/ 10.4000/artelogie.1139

Este documento fue generado automáticamente el 11 abril 2022.

Association ESCAL 


\title{
Imagen, texto y artefacto. La fotografía etnográfica del Gran Chaco argentino en publicaciones impresas contemporáneas
}

\author{
Alejandra Reyero
} indígenas de la región argentina del Gran Chaco ${ }^{1}$ en publicaciones especiales, comúnmente conocidas como fotolibro, libro-ensayo fotográfico o libro-álbum. Discutir el alcance de estos formatos como artefactos culturales, a partir del análisis de dos casos: la producción del fotógrafo norteamericano Patrick Liotta y la del argentino Rubén Romano. La primera fue elaborada en 1990 y se incluyó en el libro Tierra Adentro (editado en 2006); la segunda entre 1990 y 2008 y fue publicada en Pobladores del horizonte. Pueblos wichí y chorote hoy (2010).

3 La hipótesis que nos guía sostiene que la incorporación de la fotografía etnográfica chaqueña ${ }^{2}$ en el contexto editorial de estas publicaciones abre un espacio de disenso en términos de Rancière (2011)- respecto de los usos, sentidos y funciones tradicionalmente asignados a la imagen fotográfica de pueblos indígenas. Si bien las imágenes fotográficas mismas, revelen que los fotógrafos actuales permiten la participación e intervención activa de las comunidades indígenas y de este modo se alejan de los viejos estereotipos de percepción del otro, su inclusión en los libros genera una descontextualización etnográfica tal que las comunidades retratadas vuelven a estar asociadas a viejos paradigmas exotizantes.

$4 \quad \mathrm{Al}$ responder a procedimientos singulares de montaje y diagramación donde el vínculo imagen-palabra adopta caracteres especiales, las publicaciones otorgan al texto escrito la función de complejizar el acceso demasiado fácil y rápido a la imagen. Pero lejos de reconocerle consistencia e identidad ética y estética a las fotografías, las tornan más ambiguas. La falta de claridad respecto de la autenticidad documental de los relatos y 
testimonios citados, así como el uso de epígrafes e información etnográfica complementaria, forma parte del manejo del material verbal para adaptarlo a los propios gustos e intereses comerciales de los editores (que por lo general son los mismos fotógrafos). Esta política de la mirada afecta tanto la obtención de los registros, como la diagramación-formato de los libros y su lectura e interpretación.

En términos teórico-metodológicos esta indagación se inscribe en una perspectiva hermenéutica fundada en el reconocimiento de las condiciones históricas a las que se somete toda comprensión humana (RICOEUR, 2008: p.173), pero también en el reconocimiento de su dimensión crítica, según la cual todo discurso es capaz de trascender sus propias condiciones psico-sociológicas de producción y abrirse hacia una serie ilimitada de lecturas ellas mismas situadas en contextos socio-culturales siempre diferentes ${ }^{3}$.

A partir de este marco de referencia conceptual y procedimental, se explora y analiza el uso de la fotografía etnográfica chaqueña como material de exhibición en las publicaciones especiales antes mencionadas. En dicho contexto nos interesa identificar la dimensión visible (imagen) y la dimensión enunciable (palabra-texto). Describir el rol y función de las fotografías en la diagramación y composición de las publicaciones impresas (ubicación, formato, ángulos, recortes, técnica) y su relación con la descripción textual: epígrafes, índice, información etnográfica de los retratados, títulos de los capítulos, testimonios-citas, etc. El objetivo principal es entonces, indagar las posibilidades, efectos y motivaciones de la relación entre imagen y palabra, o lo que es lo mismo, el grado de equivalencia, (in)dependencia y colaboración entre ambas.

7 Para ello resultan cruciales las nociones de interpretación evocativa e interpretación develativa ${ }^{4}$ como principios metodológicos del análisis visual, formulados por Diego Lizarazo en base a las ideas centrales de las hermenéuticas de Georg Gadamer y Paul Ricoeur. A su vez consideramos importantes los aportes de Roland Barthes $(2008,2003)$, sobre la noción de texto y las de Han Belting (2007) e Ian Mukarovsky (en Lizarazo, 2004) sobre artefacto y objeto estético.

8 La producción del norteamericano Patrick Liotta realizada en los años noventa en Argentina, es un claro ejemplo de la conjunción entre intereses documentales y estéticos a la hora de retratar fotográficamente a comunidades indígenas ${ }^{5}$. Si bien la mayoría de las imágenes presentan una calidad estética definida tanto por los ángulos y enfoques privilegiados como por los puntos o referentes escogidos para las tomas, las mismas cobran un matiz especial cuando se las lee en el marco discursivo en el que se insertan. Noventa y seis fotografías integran el libro Tierra adentro, editado en 2006 por Cukierman Sánchez Editores ${ }^{6}$. (Imagen 1) 
Imagen 1. Fotografía de la tapa del libro Tierra Adentro

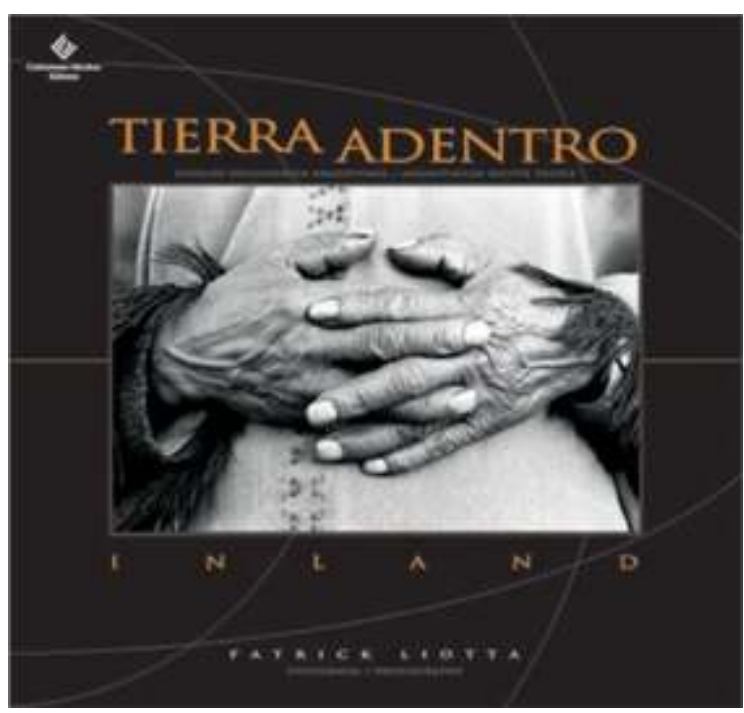

Copia extraída de URL : http://www.patrickliotta.com/site.html. Consulta : 22/7/14.

9 El libro se inicia con una presentación general del autor en la solapa delantera que comenta los motivos del proyecto fotográfico: "buscar a los olvidados y hacer un recorrido visual por sus comunidades" (...) ayudar a estos pueblos ancestrales, que tanto han sido engañados durante más de quinientos años de injusticia y olvido" (...) experimentar un viaje "inolvidable y mágico".

Luego de este preludio, la publicación se inicia con una introducción en la que los términos "belleza", "dignidad" y "delicadeza" se advierten en la voz del prologuista José Luis Castiñeira de Dios -para entonces Secretario de Cultura de la Nación Argentina-. Se suman expresiones como la "inmensa humanidad de los retratados" que allanan el terreno visual que nos espera y nos preparan para su mirada. Con una evidente carga poética las palabras tejen una suerte de "anteojeras románticas" que direcciona nuestra vista llevándonos a buscar en las imágenes ese "ojo amoroso" que según Castiñeira posee el fotógrafo y que se aleja del "europeismo desafortunado" y el "estrecho pensamiento criollo" (Castiñeira de Dios, en LIOTTA, 2006: p. 4) que tradicionalmente han mirado a los pueblos indígenas de la Argentina. Este halo sensible que crea la atmósfera de nuestra visión se complementa con una idea que termina por convencernos de que vamos a presenciar -tal como lo dice el mismo Liotta en la solapa delantera- "un acto de justicia visual" (LIOTTA, 2006, p. 3).

11 Al girar la primera página tras la introducción, nos encontramos con sutiles tomas en blanco y negro, con sugestivos recortes y puntos de vista que nos muestran sujetos en situaciones diversas. Cada imagen ocupa la totalidad de una página y aparece acompañada de un título descriptivo y literal -la mayoría de las veces- contenido en una o dos palabras: "La gomera", "Fútbol", "El predicador", "La bicicleta", "La mesa", etc. Expresiones que aluden a algún aspecto evidente de la fotografía en cuestión: si el epígrafe afirma "La gomera" vemos este objeto en algún punto de la imagen [] (Imagen 2). En el caso "El predicador", es un sujeto en el acto de predicar el que se divisa en el recorte (Imagen 3) y así sucesivamente. Los datos concretos referidos a la fecha y lugar de registro aparecen aparte, en un índice ubicado al final de la publicación y ordenado según el número de página donde se ubica cada fotografía. 
Imagen 2. Patrick Liotta. Tierra Adentro, pagina 28. En índice : Niño wichí luego de cazar un pajarito. Salta, 1995.

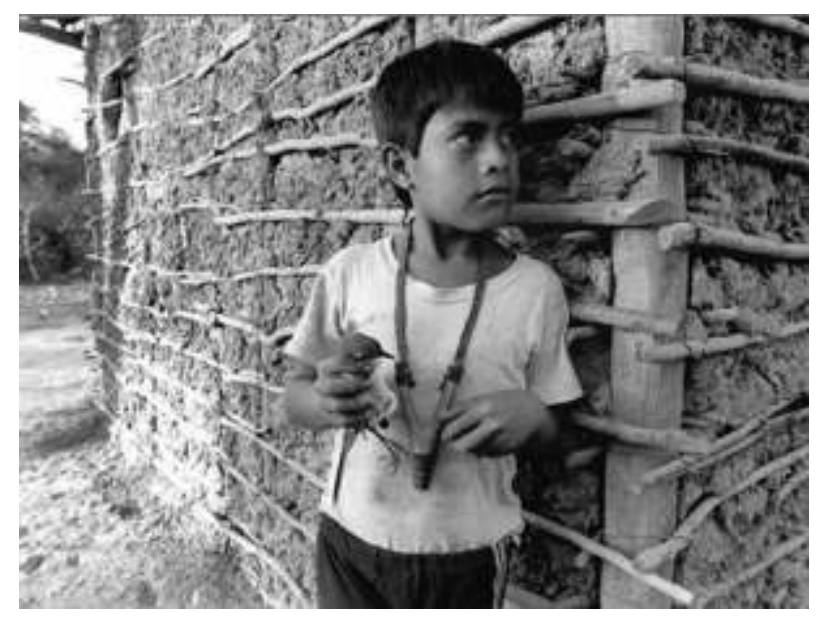

Copia extraída de URL : http://www.patrickliotta.com/site.html. Consulta : 22/7/14.

Imagen 3. Patrick Liotta. El predicador, p. 56. En índice : Templo evangelista. Comunidad toba, Chaco, 1994.

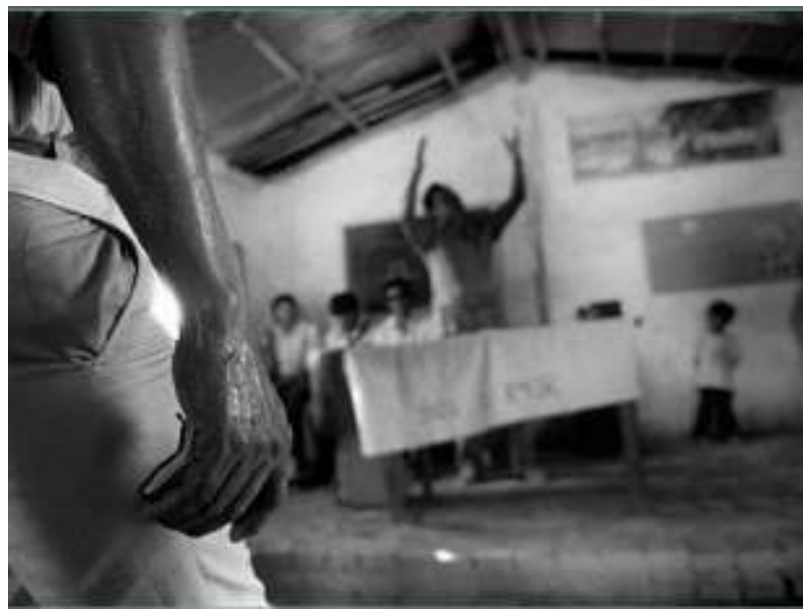

Copia extraída de URL : http://www.patrickliotta.com/site.html. Consulta : 22/7/14.

12 Muchas de las tomas revelan una presunta interacción y confianza con quien aprieta el disparador de la cámara y ello se expresa en las actitudes y gestos espontáneos y un tanto naturales de los retratados (Imágenes 4 y 5). Otras son imágenes de interiores (viviendas personales) y exteriores (espacios naturales) de distintas localidades que trazan una imaginaria línea cartográfica que se extiende de sur a norte del territorio argentino. Se trata de escenas de la vida cotidiana de la comunidad mapuche, wichí, toba, mocoví, kolla y guaraní, cuyos aspectos compositivos nos hacen reflexionar sobre varias cuestiones. 
Imagen 4. Patrick Liotta. Amistad, p. 32. En índice : Limpiando zapatillas en el Río Bermejito. Comunidad toba, Chaco, 1994.

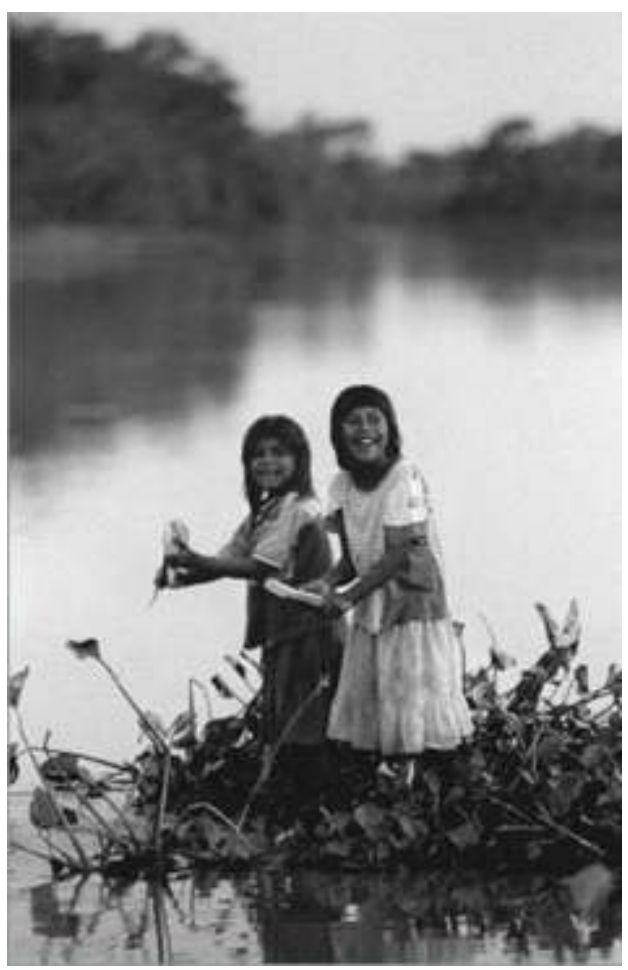

Copia extraída de URL : http://www.patrickliotta.com/site.html. Consulta : 22/7/14

Imagen 5. Patrick Liotta. Espantapájaros, p. 54. En índice: Huerta de una familia toba, Chaco, 1995.

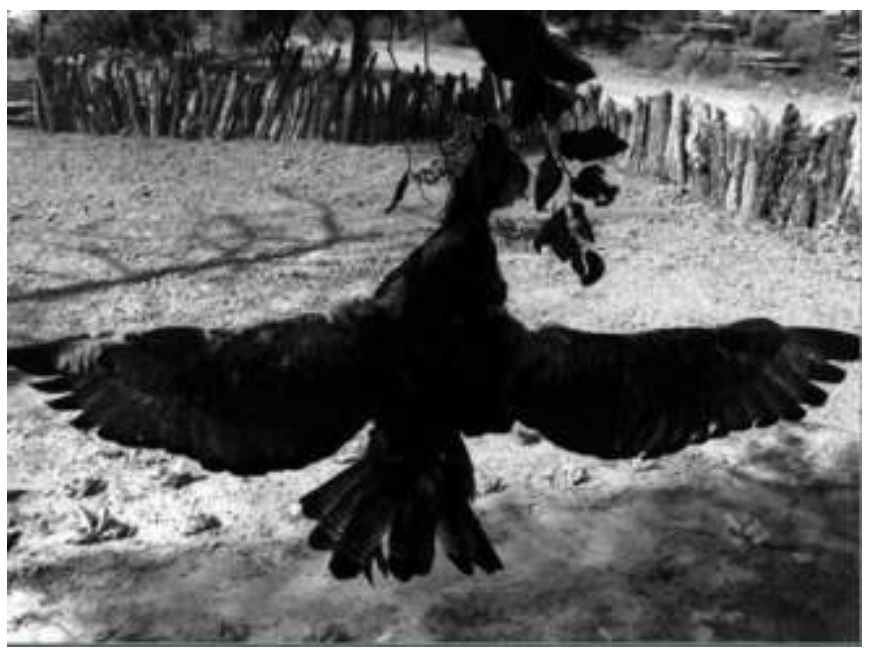

Copia extraída de URL: http://www.patrickliotta.com/site.html. Consulta: 22/7/14.

Independiente del innegable detenimiento -congelamiento de las tomas (toda foto es naturalmente estática: el registro de una acción en un espacio y tiempo determinado), todas revelan una distancia de los convencionales registros de pueblos indígenas. A todas las atraviesa un dinamismo que excede y supera la propia acción capturada, que trasciende el recorte fotográfico. Los sujetos que vemos no posan ante la cámara, sino que ésta los registra en el instante en que se encuentran haciendo algo (jugando, cazando, predicando, etc.); de modo que se asumen como sujetos activos dentro de su 
comunidad. Este dinamismo se intensifica por las decisiones técnicas y formales del fotógrafo, por los ángulos elegidos, los recortes empleados que captan a los sujetos en gestos y actitudes que no parecen advertir la presencia de la cámara ante ellos, o cuando lo hacen expresan en sus rostros cierta complicidad con el fotógrafo. (Imágenes 6 y 7). En el caso de "Fútbol", por ejemplo, el recorte excluye de la toma a los rostros de los niños que juegan, evidenciando sólo parte de sus cuerpos sentados en el suelo y sus manos manipulando los muñequitos de barro. El protagonismo es así atribuido a los instrumentos del juego y no a quienes juegan, como podría esperarse convencionalmente de una fotografía que lleva por referencia tal descripción.

Imagen 6. Patrick Liotta. La bicicleta, p. 45. En índice: Niñas tobas en el campo. Chaco, 1995.

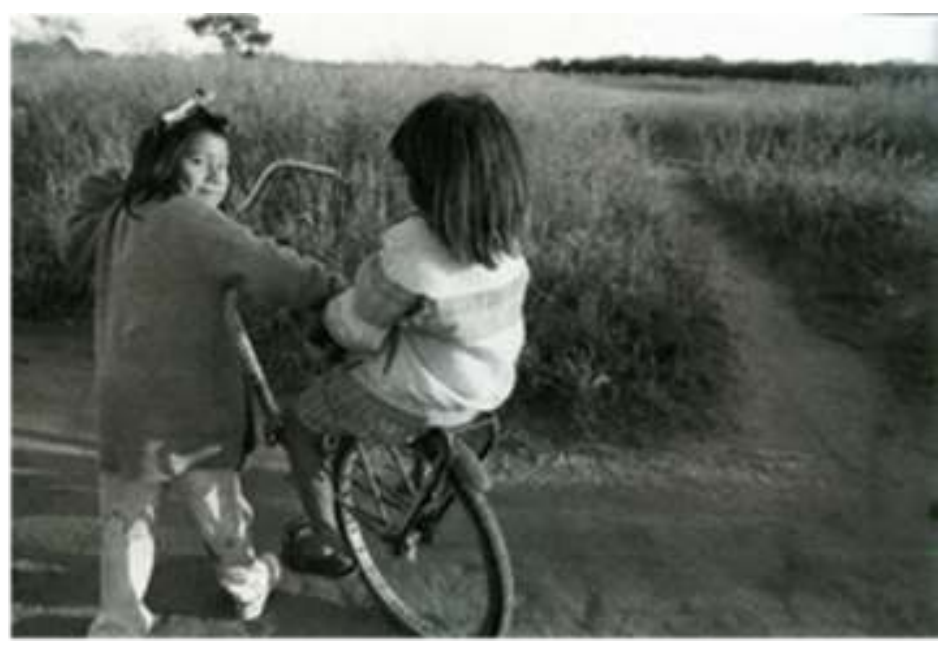

Imagen 7. Patrick Liotta, La mesa, p. 34. En índice: Niña toba en su casa. Chaco, 1995.

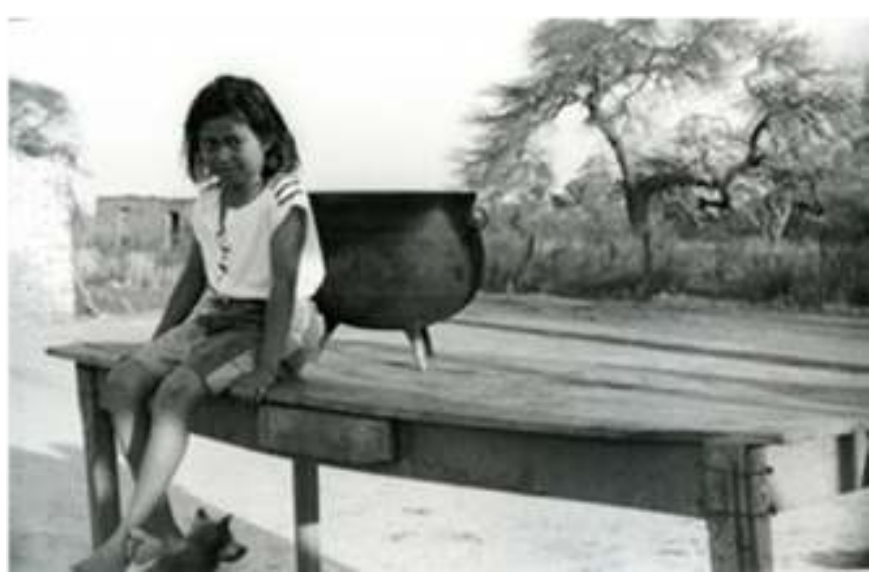


Imagen 8. Patrick Liotta. Fútbol, p. 29. En índice: Muñequitos de barro jugando la Copa del Mundo. Comunidad pilagá, Salta, 1994.

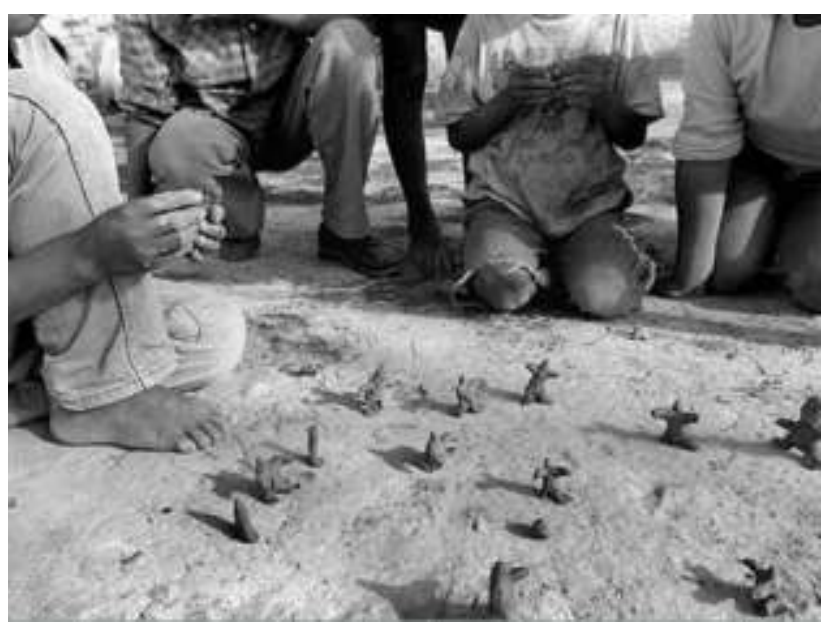

Copias extraídas de URL: http://www.patrickliotta.com/site.html. Consulta: 22/7/14. presentación -la publicación en el libro- advertimos no sólo las expresiones naturales y espontáneas de los sujetos en el marco de momentos, instancias y situaciones singulares, sino también signos de ciertos estereotipos. Ello ocurre cuando -de acuerdo a lo planteado por Lizarazo (2004)- somos capaces de someter la imagen a una modalidad de lectura que pasa de la evocación, (mediante la cual se sugiere, propone o indica un sentido) a la develación (que requiere de un posicionamiento crítico y una mirada aguda a través de la cual no sólo intentamos describir sino también explicar lo que vemos). su lectura crítica, es el reconocimiento de dos aspectos vinculados entre sí: por un lado, la presencia de la naturaleza -que históricamente ha acompañado la iconografía fotográfica sobre el indígena en general y chaqueño en particular- y por otro, la referencia a un colectivo étnico. Si bien en la producción de Liotta la naturaleza se exhibe en el contexto general de las tomas, su presencia no deja de recordarnos viejas concepciones en nuevas imágenes.

predominantes en ellibro aluden mayoritariamente a la geografía sureña del territorio argentino. Pero las correspondientes a la zona chaqueña (dieciocho en total) tienen también en común la referencia notoria de la naturaleza actuando de trasfondo de las tomas. A lo largo de la publicación la naturaleza vuelve a ser elegida una vez más como el tópico "unificador" ${ }^{8}$. Lo singular en esta oportunidad -sin embargo- es la opinión del propio fotógrafo al admitirla como algo común a la diversidad de comunidades retratadas. En una entrevista en la que se le preguntó por las similitudes entre los pueblos indígenas que retrató, el autor respondió aludiendo al "respeto de las comunidades por la naturaleza y el medio ambiente en general" ${ }^{~}$. Este parecer del fotógrafo no sólo da cuenta de su posicionamiento ideológico respecto de la realidad que decide fotografiar sino que se advierte explícitamente en los registros en los que da a la naturaleza un protagonismo importante.

Por su parte, los epígrafes que acompañan a las imágenes inmediatamente en la misma página donde aparecen, aluden también a generalidades de la escena como "Río", 
"Fútbol", "Botella", "Espantapájaros". El nombre de los retratados o el de la comunidad a la que pertenecen, se explicitan sólo en el índice ubicado al final del libro; lo que lleva a preguntarnos si la decisión de identificar de esta forma a las imágenes no acentúa las "similitudes" entre los retratados, más que sus diferencias. De esta forma, en el hecho de no nombrar al retratado, ¿no se esconde aquel patrón ideológico del siglo XIX que se resumía en la expresión "visto un indígena, visto todos" y que lejos de reconocer la identidad individual del sujeto retratado lo identificaba en función de un colectivo étnico? Para entonces, la identidad no sólo se reducía a lo colectivo sino que además se traducía en signos, en marcas visuales que se reiteraban en los registros para remarcar la imagen del "salvaje/infiel/bárbaro": armas apoyadas en el suelo o sostenidas en las manos del retratado como evidencia de agresividad y salvajismo, desnudez o vestimenta precaria, pintura corporal, artefactos como el arco y la flecha, la pose rígida, el rostro adusto y el gesto reticente o desafiante del retratado, etc. (Giordano, 2008).

18 En cuanto a la difusión de las imágenes y particularmente del libro analizado, en la página web del fotógrafo hallamos la mención de dos exposiciones que por el título harían referencia a las fotografías que integran Tierra adentro. La primera se denomina Los sentimientos de la Tierra y fue realizada en el Congreso Nacional de Buenos Aires en 1997; la segunda La gente de la Tierra y tuvo lugar en la Biblioteca Nacional de Buenos Aires, en 1993.

19 En un portal electrónico de la Universidad de Morón (Argentina), encontramos la información de que en octubre de 1997, se realizó una exposición con imágenes de Liotta denominada Gente de la tierra, en el Salón de los pasos perdidos del Congreso de la Nación Argentina. Asimismo se informa que Greenpeace (ONG ambientalista) junto a la Secretaría de Cultura de la Presidencia de la Nación y la Secretaria de Cultura del Gobierno de la Ciudad de Buenos Aires, tramitaron la presentación del libro Tierra Adentro en la Feria del libro 2006 de Buenos Aires, y que a través de un convenio entre las comunidades indígenas y la Secretaría de Cultura de la Nación, lo recaudado mediante la venta de la publicación se destinaría a las comunidades ${ }^{10}$. En una nota publicada en el sitio del Internacional Institute UCLA de la Universidad de California, se informa que el fotógrafo junto a una cantante de la comunidad mapuche presentaron el libro Tierra Adentro en ese instituto estadounidense en noviembre de $2006^{11}$.

En tal sentido, resultan relevantes otros documentos como la página web de la editorial, donde se presenta el libro como un "importante documento visual" ${ }^{12}$, y se destaca, entre las cualidades y calidades de edición, el prólogo escrito por Castiñeira de Dios y la dedicatoria del escritor argentino Ernesto Sábato. Independiente de las intenciones comerciales, es llamativa la forma en la que la editorial denomina al producto haciendo hincapié en su dimensión documental. Al decidir llamarlo "documento" y no "producción fotográfica o libro de fotografías" está otorgando al libro cierta connotación de "objetividad", "fidelidad", "compromiso" y "respeto", que no suele asociarse a la producción artística.

En esta misma dirección -tendiente a acentuar la relevancia documental de la producción- cabe destacar la propia explicación del fotógrafo sobre ciertas decisiones de carácter técnico-compositivo. En una entrevista en la que se le pregunta por el uso del blanco y negro, Liotta remarca la "objetividad y seriedad" del documento por sobre la subjetividad y la intervención del trabajo artístico asociado comúnmente al predominio de tomas en color ${ }^{13}$. No obstante, al momento de buscar expresarse 
mediante la fotografía y reconocerse como "artista" e informar, testimoniar como "documentalista", el propio fotógrafo sitúa su producción en el umbral entre lo estético y lo documental, afirmando la complementariedad e interdependencia entre una y otra dimensión.

Finalmente resulta destacable la tentativa de legitimación de la producción fotográfica, a la que tanto la editorial del libro como del mismo fotógrafo recurren. En la web del fotógrafo hallamos un comentario, donde no sólo se insiste en la intervención del entonces Secretario de Cultura de la Nación argentina en el proyecto editorial, sino también en la cercanía del propio fotógrafo con las comunidades retratadas, en la ligazón identitaria y relación de pertenencia de quien alejado por mucho tiempo del país de sus ancestros, retorna a la tierra en la que creció y en una suerte o en un intento de "reparación histórica" hace visibles a quienes reconoce como parte de su propia vida. De allí también la significancia del título del libro: Tierra adentro, que no sólo denota sentidos evidentes como "ingreso" o "entrada" a un espacio, sino que connota también otros como "acogida", "admisión", "aceptación":

Su experiencia con otras culturas hizo a Patrick buscar a los suyos, por lo que volvió a la Argentina en busca de aprender las tradiciones y la vida cotidiana de las tribus aborígenes de su casa. Se pasó meses viviendo y compartiendo sus días con las tribus en siete diferentes provincias del campo argentino. Esta extensa obra fue seleccionada por el secretario de Cultura de Argentina y se presenta en una exposición llamada "Gente de la Tierra" ${ }^{14}$.

Como planteamos anteriormente, al pretender trascender la simple identificación y reconocimiento de lo familiar en las imágenes, es preciso interrogarlas indagando sobre aquello que llevó a que exhiban lo que exhiben. Y ello demanda, como lo evidencia la lectura desarrollada hasta aquí, un posicionamiento ante las imágenes, una búsqueda deliberada de ciertos signos que permitan conocer la trama simbólica, social, estética y política que actúa de trasfondo a su producción. La mirada inocente se vuelve perspicaz e intensa y la imagen nos desafía al punto de hacernos a desconfiar de lo que vemos; o en otros términos, nos incita a quitar la máscara de aquello que -paradójicamenteintenta proteger secretamente. Tal como plantea Ricoeur (2008). En esta instancia o bajo esta postura buscamos no sólo describir, sino también explicar lo que vemos y a través de una oscilación permanente entre ambas estrategias, llegar a comprenderlo.

En consecuencia y en el caso específico de las imágenes de Liotta, no podemos desatender el contexto mediato de las fotografías (los distintos contextos por los que circulan y se exhiben) así como el contexto inmediato (el marco discursivo del libro en que se publican), ya que ambos condicionan notablemente el contenido de cada una de las fotos y en consecuencia los sentidos a construir. Es justamente en el contexto discursivo del libro donde el empleo del término "justicia" deviene sumamente inquietante. Recordemos que la palabra aparece en la solapa delantera del libro y en la primera oración de los siete párrafos que detallan las razones de la producción fotográfica:

Fue quizás un acto de justicia ${ }^{15}$ visual, un simple impulso reflejo, pero lo cierto es que luego de ver las imágenes de las celebraciones por el quinto centenario de la conquista de América, algo me sucedió y no pude parar hasta comenzar este proyecto que me llevó casi una década desde aquel 12 de octubre de 1992.

Afirmar que la producción del fotógrafo es un acto de justicia supone en cierto modo la necesidad de amparar, de proteger dicho trabajo bajo el manto del deber y la obligación. Según la cita, el propio Liotta se vio en la "obligación moral" de responder a 
esa deuda histórica, y entonces se posicionó y decidió posicionar su cámara, en el lugar de poder privilegiado para contrarrestar "las imágenes de las celebraciones por el quinto centenario de la conquista de América". Dicho de otro modo, con esta afirmación el mismo fotógrafo acentuó y delimitó explícitamente su desigualdad con las comunidades indígenas, situándose en el lugar de poder, aquel desde el cual debe remediar, salvar y saldar años de injusticia. Desde ese lugar se sigue reproduciendo el lugar de "autoridad" de quien obtura la cámara: esa autoridad, muy común en los primeros usos de la fotografía etnográfica por parte de antropólogos, viajeros, funcionarios del Estado, etc. que se reactualiza en afirmaciones como las aludidas.

A su vez, a través de este enunciado se sobreestima en cierto punto a la imagen, pensando que si se registra fotográficamente a las comunidades indígenas, esto es: si se las muestra en imágenes fotográficas se está saldando una deuda histórica de años de postergación, marginación y olvido por parte del Estado nacional y la sociedad argentina.

Si bien es cierto que el gesto fotográfico es -en tanto decisión e intervención ideológica- válido, lo es justamente en ese plano, el visual -no menor por cierto- pero uno dentro de un conglomerado de dimensiones socioculturales y políticas que debieran dar cuenta -en el plano existencial y real- de la reparación histórica.

El prejuicio del que parten tanto Liotta como quienes editan la publicación sostiene que el libro da a conocer a las comunidades y permite que se tome conciencia sobre su existencia, lo cual es legítimo, pero dicho interés y presupuesto no se aleja demasiado de los patrones exotizantes de percepción del indígena que desde épocas remotas -en las que tuvo lugar la conformación y difusión de grabados, dibujos y pinturas- han reducido su existencia al plano meramente iconográfico : los pueblos indígenas eran tal como se veían en las imágenes.

Ambos -fotógrafo y editores- comparten la presunción que la imagen "repara", "redime" y que ellos actúan casi mesiánicamente en esa reparación. En el caso particular del fotógrafo, él no sólo tiene el "derecho a mirar", sino también la autoridad -a través de la lente- para "hacer justicia". La cámara actúa como legitimadora de un rol de autoridad. Y el libro legitima esa autoridad, porque es también una fuente de autoridad en la sociedad occidental.

30 La fotografía vuelve así a ser valorada -como hace más de dos siglos atrás- desde su supuesta capacidad metonímica de evidenciar parte de la realidad de las comunidades indígenas (aquella contenida dentro del recorte fotográfico) como si fuera toda su realidad (aquella que escapa al encuadre de la toma y aparece apenas vislumbrada en ella).

31 Recordemos que los primeros usos occidentales de la cámara fotográfica en comunidades no occidentales, actuaron como una auténtica metáfora del poder; un poder que trascendía la mera superioridad tecnológica del aparato. Las tomas fotográficas del otro constituían una apropiación de su tiempo y espacio de vida; un acto de aislamiento y descontextualización del flujo vital que pretendía demostrar alguna inferioridad respecto de quien obturaba el disparador. Las imágenes funcionaban como certificaciones no sólo de la presencia in situ del fotógrafo sino también y especialmente, de la veracidad de su registro, eran un modo de autenticar la existencia de lo registrado. 

no se inscriban en el mismo marco ideológico que sustentó las prácticas fotográficas de fines del siglo XIX, pero la mera utilización del registro fotográfico en comunidades indígenas tropieza con las contradicciones y limitaciones del propio medio fotográfico : la puesta en imágenes de algún aspecto de la realidad del otro, no sólo tiende a reducirlo a ciertos estándares iconográficos de representación, sino que también alimenta todo tipo de fantasías relacionadas con su desconocimiento. Valga insistir en que este atributo es propio de cualquier tipo de fotografía, ya que responde a la esencia misma del medio fotográfico el detener el continuum de vida de alguien limitándose a mostrar sólo un fragmento de su existencia -por lo que todo lo que escapa a ese recorte corresponde más al plano de la idealización que al de la realidad-. Pero en el caso del registro de comunidades indígenas esa condición de la fotografía asume un peso más significativo aún por la relación asimétrica entre fotógrafo (que cuenta tanto con el manejo y control tecnológico del aparato) por sobre el fotografiado (que tiende a convertirse en mero objeto de representación). El uso de la cámara es entonces una metáfora del poder con que cuenta el fotógrafo en función del lugar hegemónico que ocupa en la sociedad nacional respecto del lugar al subalterno del indígena.

Ciertamente el vínculo asimétrico entre Liotta y sus retratados es menor en comparación con los registros pretéritos. La mayoría de los gestos y actitudes de los retratados dan cuenta de un acuerdo con el fotógrafo, por lo que ninguna de las fotos es en sí el resultado de un acto "desautorizado" como ocurría habitualmente en el pasado, pero aún atenuada, la asimetría se mantiene, y ello se explicita -como dijimos- en el contexto discursivo en el que se publican las imágenes, así como en los otros espacios de difusión por donde circulan.

De este modo, las anticipaciones y preconceptos que guían la producción de Liotta dan lugar -en términos de Gadamer (2003)- a la manifestación de la visión histórica sobre los pueblos indígenas chaqueños. Esta visión -fundamentada en la tradición y la autoridad- se reafirma en la visión del propio Liotta expresada no tanto en sus imágenes como en el discurso que las justifica, el cual se halla sustentado y constituido por un tramado de prejuicios solidarios que tejen la tensión entre extrañeza y familiaridad (LIZARAZO, 2004 : p. 31).

No obstante, retomando a Ricoeur (2003; 2008), no podemos -en tanto intérpretesreducir el sentido de las fotografías a una lectura como ésta que devele la intención del autor, en este caso, el fotógrafo. El problema de la comprensión no se resuelve mediante el simple retorno a la intención del autor. No es suficiente con la supuesta "captación de su vida psíquica", sino que se requiere de un conjunto de procedimientos explicativos que precedan y acompañen -o en otros términos que mediaticen- la comprensión (Ricoeur, 2008).

36

Entre tales procedimientos, los prejuicios que guiaron al propio Liotta a obtener esas fotos, como a nosotros a arriesgar una lectura, conforman -siguiendo a Gadamer- la pregunta para la que las imágenes son respuesta. Es decir, la pregunta que las fotos tanto por sí solas como por el contexto editorial donde aparecen publicadas, responden. Y ella sería: “ ¿puede la fotografía -en tanto medio de registro y expresióndar cuenta de dónde y cómo viven las comunidades indígenas argentinas hoy? Y de esta forma, ¿hacer que quienes veamos las imágenes reconozcamos entidad e identidad a tales comunidades?" 

otras respuestas posibles; por lo que las imágenes de Liotta son sólo una entre muchas respuestas, pero sólo ellas abren en esta ocasión y ante nosotros intérpretes, un mundo digno de atención. Y ello particularmente por la forma en la que son usadas en el contexto del libro y los demás espacios por donde circulan. Reiteramos, no son las fotos mismas en sí lo discutible, sino el discurso que las acompaña, que las ordena y que les da un marco particular que se abre a la interpretación. Podríamos entonces afirmar que es en el uso o difusión de las fotografías en el formato de libro donde debiera asentarse la lectura crítica, ya que allí se juega o se explicita la manipulación ideológica sobre las comunidades retratadas.

El otro caso de análisis corresponde a la producción de Rubén Romano ${ }^{16}$, realizada entre 1996 y 2008 en la región del Chaco salteño e incluidas en el libro Pobladores del horizonte. Pueblos wichí y chorote hoy ${ }^{17}$.

Imagen 9. Fotografía del libro Pobladores del horizonte

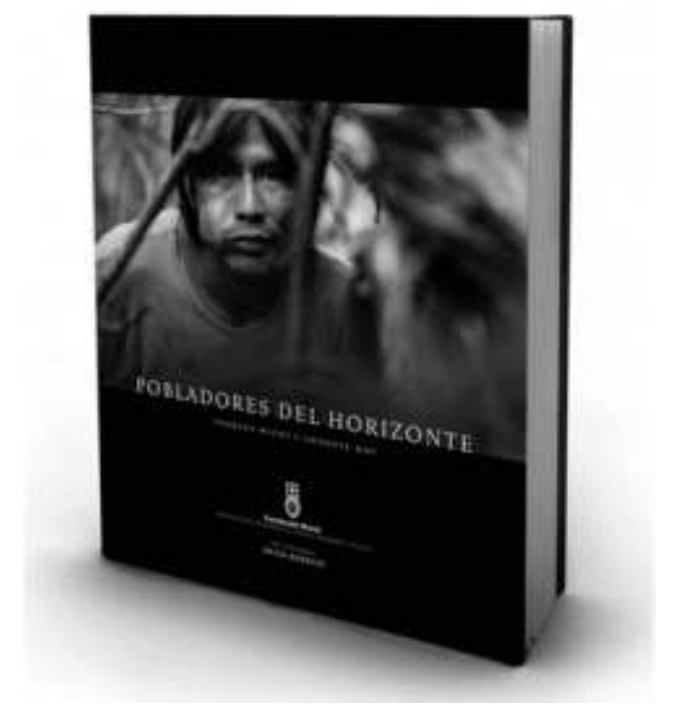

Copia extraída de URL : http://rubenromano.com/galeria.php?numero=200. Consulta : 22/5/13.

Una de las características destacadas de estas imágenes es el predominio de retratos de medio cuerpo y cuerpo entero, particularmente de niños, quienes se muestran en poses, gestos y actitudes espontáneas. El escenario del registro suele ser siempre la naturaleza (fondos naturales en los que se sitúan los retratados); unas pocas veces el paisaje aparece sin presencia humana. En el caso de hombres y mujeres adultos ciertas imágenes los muestran realizando tareas y trabajos cotidianos como el tejido, la pesca y la recolección. En términos compositivos-formales, se destacan los fuertes contrastes de luz.

Deteniéndonos particularmente en el libro como artefacto, cabe mencionar que las imágenes que integran la publicación no sólo pertenecen a Rubén Romano, sino también de otros dieciséis fotógrafos que realizan sus registros en el marco de un proyecto de recuperación, revitalización y difusión de la música y la danza de comunidades wichí y chorote del noroeste argentino.

Dicho proyecto, que se inició en 1987 y continúa vigente actualmente, se denomina Argentina indígena. Fue un emprendimiento de la antropóloga y cantante Silvia Barrios y 
contó con el apoyo de la Fundación Norte ${ }^{18} \mathrm{y}$ el auspicio de las embajadas de Alemania y Suiza. Argentina indígena es también el nombre de un espectáculo, resultante del proyecto, en el que participan de forma conjunta los maestros del canto y de la danza de cada pueblo, y que se presenta a nivel internacional desde 1987 con la dirección de Silvia Barrios ${ }^{19}$.

Si bien las imágenes de Romano no son las únicas dentro del libro, se destacan del resto por el número y formato en el que aparecen y es por ello que decidimos analizarlas especialmente. La primera de sus imágenes aparece en la tapa de la publicación y en el interior suman un total 162, de las cuales sólo veintiséis son en color. Todas aparecen sin referencia o epígrafe inmediato acompañando cada registro, ya que las descripciones se ubican al final del libro en un Índice fotográfico con los créditos correspondientes de los autores e información básica como lugar y fecha del registro ${ }^{20}$.

En su totalidad el libro se organiza en cuatro partes: la primera corresponde al prólogo escrito por Silvia Barrios (directora general del proyecto y a su vez de la publicación). En este apartado la misma explicita el objetivo y finalidad del proyecto y del libro : "no es intención profundizar en ninguno de los aspectos de la vida de estos pueblos sino más bien presentarlos de una forma lo más abarcativa posible, ante un país que los desconoce, separa e integra compulsivamente, que los discrimina y estereotipa" (BARRIOS, 2010: p.8). Respecto de las frases y comentarios que acompañan las imágenes a lo largo de todo el libro se aclara lo siguiente: "hemos querido ir engarzando innumerables anotaciones y apuntes sonoros, principalmente en el hilo de un solo discurso (...) que intenta traducir lo que consideramos sustancial de sus ideas y opiniones respecto de cada tema" (BARRIOS, 2010 : p. 9).

Siguen al prólogo treinta y tres capítulos, un epílogo ${ }^{21}$, el índice fotográfico ya mencionado, los agradecimientos y un DVD de música y video ubicado en el interior de la contratapa. En lo que sigue y dadas las limitaciones de extensión establecidas para este trabajo, analizamos sólo siete de estos capítulos y el epílogo del libro ${ }^{22}$ :

El capítulo nueve se denomina "El monte, los colores de la memoria" y pone el acento en la producción artesanal de las comunidades retratadas. Predominan aquí los registros de los tejidos realizados en color, pero también imágenes del proceso de elaboración. De las once imágenes, seis pertenecen a Romano; de las que se destaca una en color que tiene como referencia la siguiente descripción: "Poniendo a secar las fibras, Santa Victoria, 2008" (uno de los pocos epígrafes que comprende las tres dimensiones más importantes para la contextualización del registro : tipo de actividad o escena capturada, lugar y fecha de la captura). La imagen muestra a tres jóvenes colocando fibras de la planta de chaguar sobre una rama, ninguna mira al fotógrafo, todas están concentradas en su labor. (Imagen 10) 
Imagen 10. Rubén Romano. Cap. Monte. Colores de la memoria, p. 96 . En índice : Poniendo a secar las fibras, Santa Victoria I, 2008.

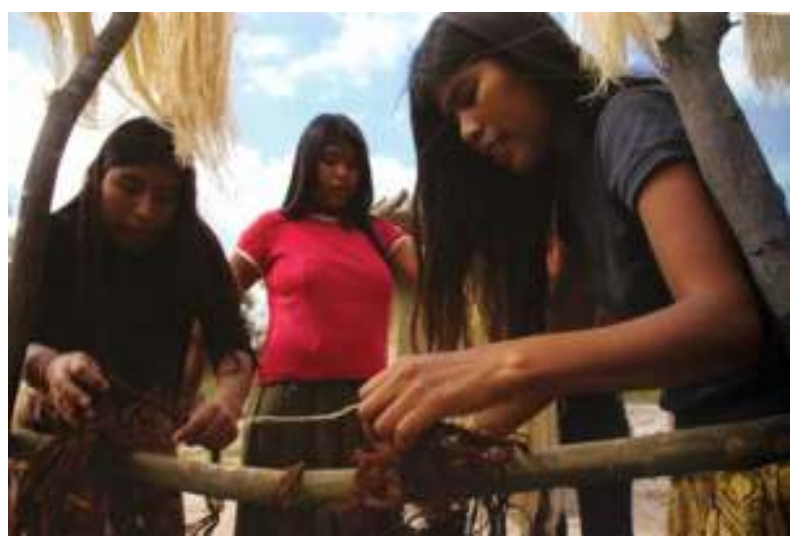

Este capítulo tiene la particularidad de sumar a los registros contemporáneos otros realizados en la década de 1980, en blanco y negro, pero no se menciona por quién, ni a qué lugar corresponden. Cierra este capítulo una toma de Rubén Romano sin datos de lugar, ni fecha y en blanco y negro. Se trata del registro de un hombre quien se ubica de pie casi de espaldas a la cámara en la actitud y con el gesto de caminar, acompañado de un perro. El escenario es un camino del monte que se abre en medio de filas de árboles secos a ambos lados. El epígrafe de la imagen contribuye nuevamente más que a aclarar e informar, a generar ambigüedad y ello se intensifica por utilizar una expresión en lengua wichí, "tokuaj", noción que alude -en la cosmovisión animista y chamanística wichí- a un ser superior de la naturaleza que rige el mundo. (Imagen 11)

Imagen 11. Rubén Romano. Cap. El monte / Los colores de la memoria, p.105. En índice : Como tokuaj.

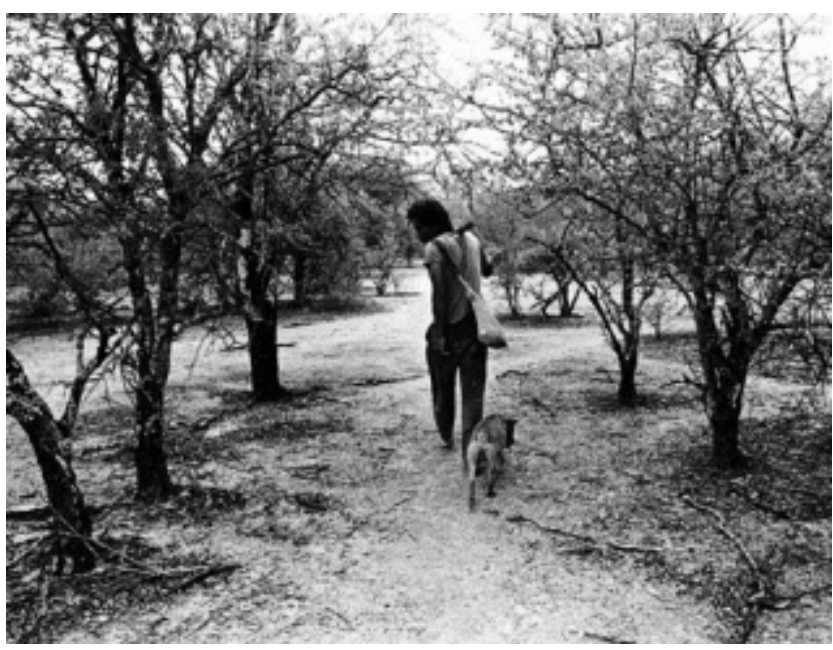

Copia extraída de URL : http://rubenromano.com/galeria.php?numero=200. Consulta : 22/9/14

El capítulo siguiente se denomina "La gente de conocimiento. Cosmovisión" y la portada aparece ilustrada por una imagen de Romano, en color. Se trata de un ave sobre las ramas de un árbol, la referencia es la siguiente: "Guailán". El capítulo completo contiene nueve imágenes, de las cuales tres son históricas (obtenidas -por la calidad y definición técnica de las tomas- probablemente a principios del siglo XIX, pero de las que se desconoce autor, lugar y fecha exacta del registro). Se suman otras 
cinco contemporáneas (realizadas por Rubén Romano). Las dos últimas parecen recortes de retratos, una sobre las manos de un anciano, la otra sobre los ojos de un hombre. Dos exhiben materiales u objetos de algún ritual y otras dos son retratos de dos hombres, uno en una aparente actitud de mostrar un objeto que no llega a percibirse con claridad, pero que parece corresponder a una bolsa tejida, y otro ubicado de frente sosteniendo dos objetos, uno en cada mano y mirando fijamente al fotógrafo. La referencia de la imagen dice: "Jayawú preparado para pelear". Todas las imágenes están entremezcladas con relatos o fragmentos de diálogos, pero de nuevo no se sabe a quién corresponden (de dónde están tomados, quién o quiénes los pronunciaron y en qué contexto). Ninguno explicita una relación directa con las imágenes. (Imagen 12)

Imagen 12. Rubén Romano. Cap. La gente de conocimiento. Cosmovisión, p. 111. En índice: Jayawú preparado para pelear.

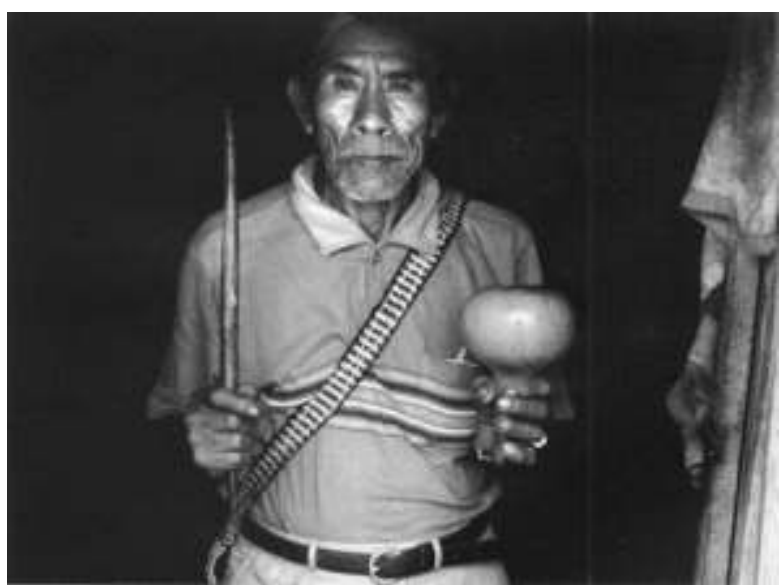

El capítulo trece se denomina "La caza"; tiene en la portada una imagen de Romano cuya referencia indica "Cazador con yicas, Misión La Paz, 2006". (Imagen 13). De nuevo es en blanco y negro, y se trata del retrato de un hombre. Le siguen nueve fotografías de las cuales seis son de Romano. Se destacan "Búsqueda y encuentro del Gualdote", que registran una escena de caza, sujetos en acción, realizando sus tareas cotidianas. Ninguno posa como en los registros pretéritos. Se mueven, accionan, y las tomas parecen espontáneas: los sujetos se olvidan de la cámara y ésta los registra como si el fotógrafo no estuviera allí.

Imagen 13. Rubén Romano. Cap. La caza, p. 142.En índice: Cazador con yicas.

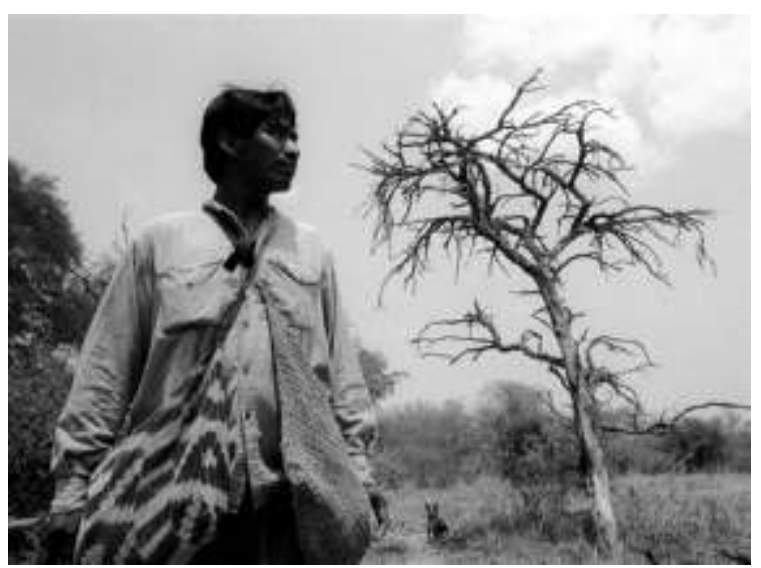

Copia extraída de URL : http://rubenromano.com/galeria.php?numero=200. Consulta : 22/9/14. 
El capítulo catorce lleva por título "La pesca" y la foto de portada retrata a hombres y jóvenes con sus instrumentos de pesca, antes de introducirse al río. Son seis y un perro. De frente y de perfil algunos, otros caminando o a punto de retomar el paso, pero -a diferencia de las imágenes anteriores- todos miran fijamente a la cámara. Todos posan. (Imagen 14). Le siguen nueve imágenes, cuatro de Romano. Sugerente es el recorte de medio cuerpo, torso-cintura de un hombre girando sobre sí mismo, y del que sólo vemos su mano derecha, parte del brazo izquierdo y algo de su torso. El epígrafe describe la escena como "Pescador y garrote" (de nuevo, no hay datos de lugar, ni fecha). (Imagen 15)

Imagen 14. Rubén Romano. Cap. La pesca, p. 152. En índice: Pescadores del Pilcomayo

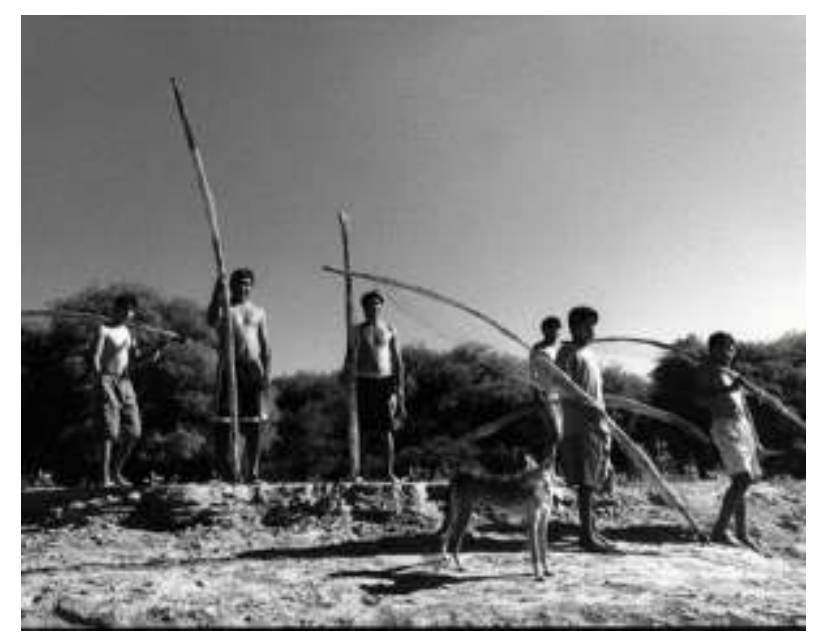

Copia extraída de URL : http://rubenromano.com/galeria.php?numero=200. Consulta: 22/9/14.

Imagen 15. Rubén Romano. Cap. La pesca, p. 157. En índice: Pescador y garrote.

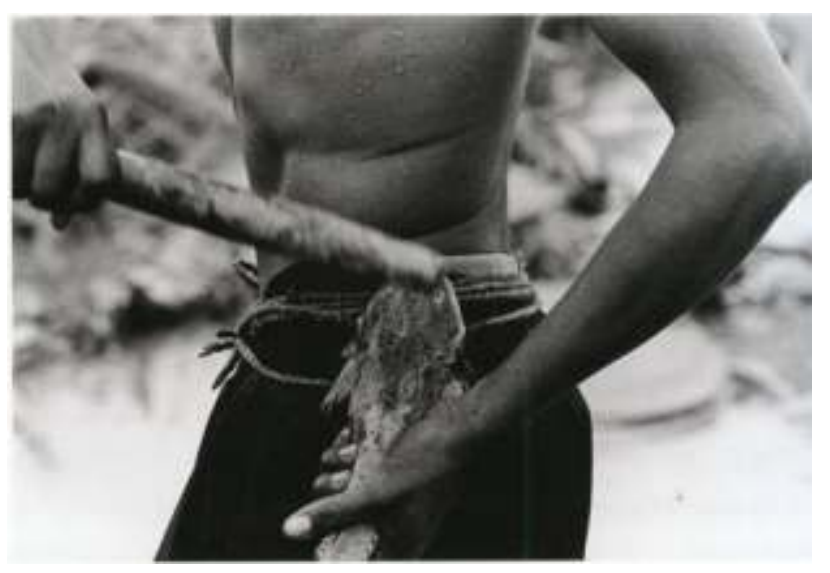

El retrato en blanco y negro de un hombre delante de una fogata encendida ilustra la portada del capítulo 24: "Katináj, los mayores". La escena parece corresponder a un ritual, lo que se deduce por el gesto y expresión del retratado, su cuerpo en movimiento, en una leve inclinación hacia la izquierda, sus ojos cerrados, su torso desnudo cubierto con adornos de plumas y collares. La referencia en el índice informa: "Huatiyó, canto para madurar la aloja, La Estrella, 2006". (Imagen 16) 
Imagen 16. Rubén Romano. Cap. Katinaj, los mayores, p. 262. En índice: Huatiyó, canto para madurar la Aloja. La Estrella, 2006

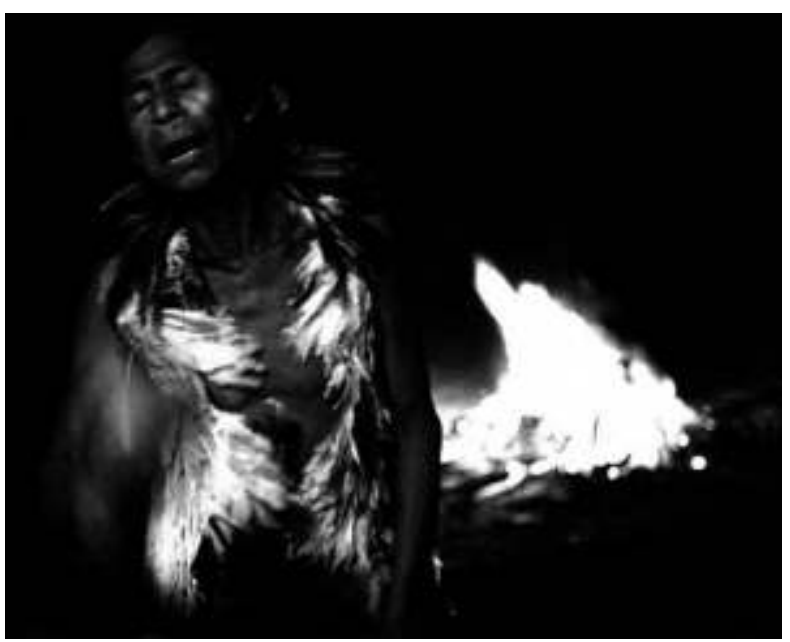

Copia extraída de URL : http://rubenromano.com/galeria.php?numero=200. Consulta: 22/9/14.

51 Se suman a esta imagen otras quince fotos, todas en blanco y negro, la mayoría sobre ceremonias y rituales de canto y danza. Catorce son de Romano. Se destacan las dos últimas: un retrato individual de la misma persona de la portada del capítulo, pero ahora de cuerpo entero, por lo que se ve que los adornos que cubren su pecho no son collares sino una suerte de chaleco y que de sus piernas cuelga una falda de piel. Con unas de sus manos sostiene un instrumento musical. Es la misma escena de la imagen anterior pero desde otro ángulo, el fuego del fondo cobra mayor relevancia así como un tronco o trozo de madera en primer plano con un vaso sobre él. La referencia en el índice es la misma que la de la portada: "Huatiyó, canto para madurar la aloja, La Estrella, 2006". Le sigue a esta toma, una imagen en formato horizontal, más pequeña donde se ve a la misma persona pero ahora de perfil dirigiendo su cuerpo y mirada a otro hombre que se encuentra de frente precedido por el tronco o trozo de madera que ocupaba el primer plano en la imagen de mayor dimensión. Esta imagen pequeña tiene una referencia directa a pie de foto: "Madurando, celebrando. Uetín y Huatiyó", y un fragmento de texto que por su contenido suponemos que se trata del relato de algún miembro de la comunidad retratada, (pero de nuevo no aparece referencia alguna sobre quién, cuándo y dónde lo expresó). Sólo advertimos algunas menciones en el texto a la figura del maestro Uetín que brindan ciertas "pistas" sobre la imagen. La cita alude a su sabiduría y conocimiento ancestral acerca del canto y una reflexión-interrogante acerca de su destino una vez muerto.

52 Un retrato grupal de niños mirando hacia el plano superior de la toma, rodeados de fuertes contrastes de luz desde un foco que pareciera ubicarse justamente por encima de ellos, ilustra el capítulo 25 : “Katináj, los niños”. La imagen ocupa la mitad de la página completa de la portada. Los niños sonríen y se hallan en una actitud de "goce contemplativo". Algo observan pero el recorte de la toma nos impide ver qué, sólo advertimos que se ubica por encima de ellos y del mismo fotógrafo, de quien por cierto no se percatan o se olvidan por un momento, y al hacerlo nos invitan a nosotros (espectadores) a olvidarnos también de la presencia de la cámara. Tanto en este capítulo como en otros, muy pocas imágenes registran al retratado mirando directamente a la cámara, en la mayoría el retratado mira a uno de sus lados, como 
parte de un gesto o acción más amplia que involucra un entorno mayor que el que se recorta en la imagen. (Imagen 17)

Imagen 17. Rubén Romano. Cap. Katinaj, los niños, p. 276. En índice : Baño de luz y música. La Estrella, 2006

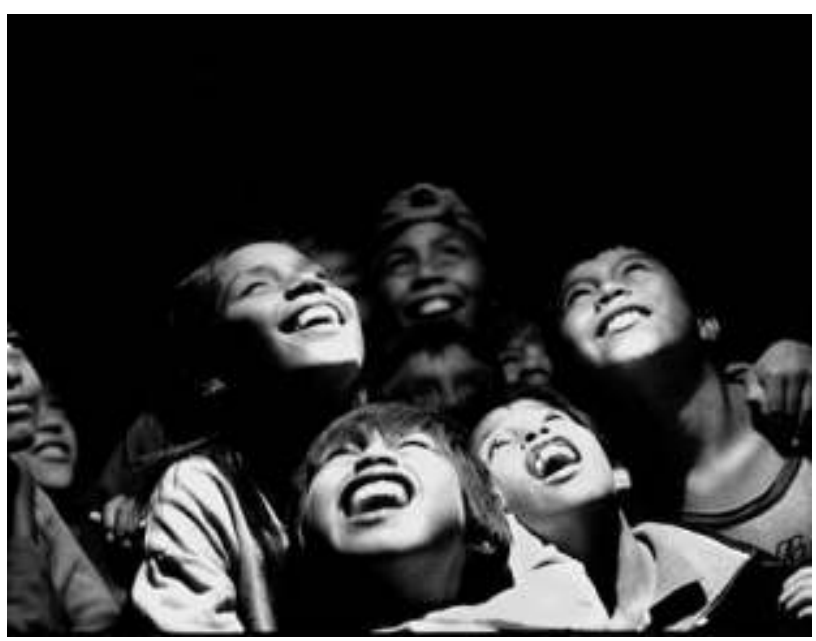

Copia extraída de URL : http://rubenromano.com/galeria.php?numero=200. Consulta : 22/9/14

El capítulo siguiente se denomina "Los brotes de la esperanza" y se compone de ocho imágenes, de las cuales tres son de Romano. Una en color, "Tareas escolares” muestra a una joven y un niño mirando un cuaderno escolar sentados juntos ante la cámara, pero sin percatarse de su presencia; otra imagen también en color corresponde al retrato de un niño asomado sobre una ventada en el interior de una vivienda. Y la última, es la huella de un pie sobre la tierra que cubre toda la dimensión de la página completa junto al siguiente comentario:

Así vamos dejando nuestro rastro en la tierra... para muchos a veces no se ve. Como los curanderos criollos y los Jayawú cuando curan a los animales agusanados, ¿tendremos que dar vuelta el rastro, para que se cure la bichera del olvido, del silencio obligado? (BARRIOS, 2010 : p. 296).

Imagen 18 Rubén Romano. Cap. Katinaj, los niños, p. 297. En índice: Rastro, Pilcomayo salteño, 2008

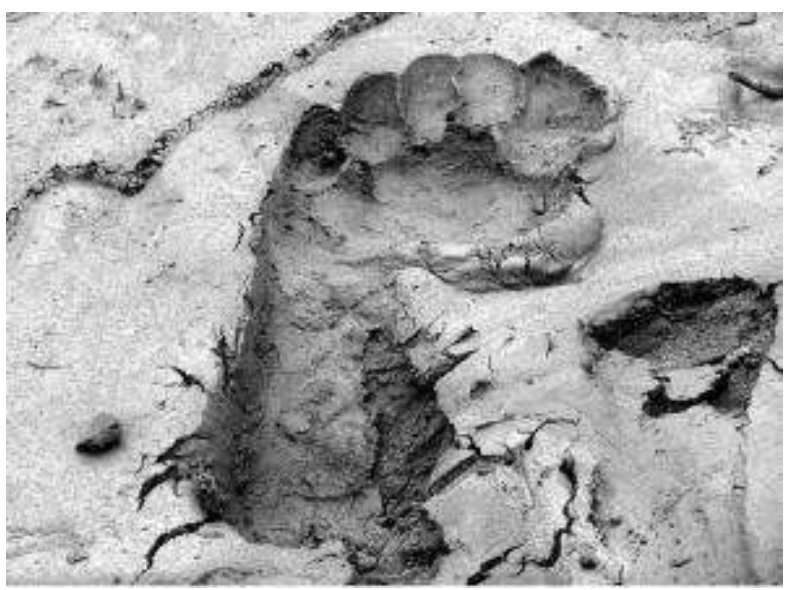

Copia extraída de URL: http://rubenromano.com/galeria.php?numero=200. Consulta: 22/9/14 
54 frases y testimonios que ponen en evidencia los deseos de los adultos de que sus tradiciones sigan vivas entre los más jóvenes y especialmente que se logre el reconocimiento de la sociedad nacional mediante las distintas presentaciones, grabaciones de CD, publicación de libros, folletos, etc. Se destacan las frases:

Nuestra esperanza es que nos conozcan por lo que tenemos, no por lo que nos falta (...) estamos orgullosos. Todo el mundo puede saber ahora cómo cantamos aquí. Y los chicos pueden aprender. O por lo menos que los brotes de nuestro pueblo sientan cómo cantaban los árboles añosos (...) Hay nuevos, que como nosotros los Antiguos, esperan a Ifwala, la luz del Amanecer...un tiempo en que todos volvamos a nacer (BARRIOS, $2010: 292-295$ ).

Llegados a este punto y concluida esta descripción general, la primera lectura del libro completo sugiere que el mismo no está concebido para un público especializado ni académico, sino más bien un público general, desinteresado por cuestiones etnográficas particulares y atento al valor iconográfico de las imágenes por sí mismas.

to singular es que la información etnográfica sobre las comunidades retratadas aparece recién en el índice general ubicado al final de la publicación en lo que los editores llaman literalmente: "Datos etnográficos". En este apartado aparecen desde cuadros escuetos hasta explicaciones más complejas sobre distintos aspectos de las comunidades (ubicación geográfica, lengua, economía, religión, organización social, salud, etc.). Lo que "inquieta" de esta organización de la información no es sólo la ubicación al final del libro como algo secundario y accesorio (lo verdaderamente importante parecerían ser las fotos), sino la falta de vinculación entre los datos etnográficos y las fotografías. Ninguna de las imágenes está referenciada por etnias, por lo que se dificulta la búsqueda de información específica en el apartado "Datos etnográficos" desde este criterio (no es posible cruzar-vincular directamente la información contenida en los "Datos etnográficos" con las imágenes mismas). Si un lector desea obtener mayores datos respecto de lo retratado en una imagen y quiere recurrir para ello a la información contenida en el apartado de libro especialmente destinado a ello, no tiene cómo vincular específicamente la foto que le interesa con la información detallada atrás.

Algo en íntima relación con esta cuestión es la ubicación misma de los epígrafes de las imágenes que también se encuentran en la parte final del libro en un índice ordenado por páginas y en un formato minúsculo en comparación con la dimensión de las fotos mismas y del libro en su totalidad. Esto no sólo dificulta la rápida ubicación de las imágenes sino que restringe nuevamente esta información (quién o quiénes son los retratados, dónde y en qué contexto fue tomada la fotografía, etc.) a un plano meramente accesorio.

Lo que esta diagramación editorial reafirma nuevamente, es que lo verdaderamente relevante son las imágenes por sí mismas. Pero a su vez, lo que también evidencia este uso de la imagen en "primer plano" dentro del libro y la relegación de la información textual complementaria, es la selección de la información que acompaña cada imagen, ya que no toda la información textual es relegada. A lo largo de la publicación las imágenes no sólo están organizadas por temas que dan origen a los títulos de los distintos capítulos, sino que también están acompañadas con relatos y testimonios anónimos de miembros de algunas de las comunidades retratadas, pero no hay forma alguna de conocer si el texto en cuestión corresponde al sujeto retratado o fue 
enunciado en el contexto al que alude la imagen o uno similar o simplemente, fue manipulado para manifestar una supuesta correspondencia con la imagen. Esto es ; si fue elegido y utilizado arbitrariamente para confirmar -mediante palabras- lo visto en la imagen.

El interrogante que se abre entonces es si el uso del texto responde a la intención de desambiguar la imagen, de restringir su dispersión semántica, de contener la multiplicidad de significados que pueda abrir, o por el contrario, generar mayor ambigüedad.

Esta es la mayor contradicción del libro : por el espacio destinado a las imágenes, por el tamaño y calidad de edición parece confiársele a éstas su poder de "comunicar, significar por sí mismas". Sin embargo los textos que las acompañan cumplen la función de contener y restringir su dispersión semántica. Su rol en la publicación es otorgar un significado particular para cada imagen, aquel que él mismo comunica por sí solo y que pretende que la imagen simplemente ilustre. De este modo, el tradicional valor y uso que la imagen fotográfica etnográfica tuvo desde sus orígenes reemerge en la actualidad, y al hacerlo pone sobre el tapete la vieja cuestión acerca de su poder comunicativo privativo versus su sometimiento a la palabra.

61 En función de lo analizado resulta importante reflexionar sobre la cualidad comunicacional de los libros Tierra adentro, y Pobladores del horizonte. Pueblos wichí y chorote hoy, en tanto artefactos culturales. Esto es, en tanto objetos dotados de propiedades materiales cuya dimensión significante de carácter histórico, social y colectivo actúa en el plano experiencial apoyado en el soporte material de las obras (Mukarovsky, en LIZARAZO, 2004: p. 72).

62 Tal como lo discutimos, de su organización estructural -de característica permanentecomo de su encuentro con la conciencia social que lo recepciona de acuerdo a valores diversos, tales artefactos pueden devenir eventualmente en "objetos estéticos". Ello ocurre, en términos de Mukarovsky (en LIZARAZO, 2004: p. 77), gracias a su capacidad, a su "energía estética potencial" para atraer otros valores. Pero su autenticidad no culmina allí sino con la intervención del intérprete con quien tiene lugar el proceso de percepción y valoración que no es sino un trabajo simbólico de "desciframiento", articulación y síntesis de los factores aparentemente extraños, sueltos y contradictorios y no una lectura literal de los mismos de acuerdo a la convención social del momento en que se produjo la obra y de aquel en que se la recepciona.

En este sentido, y en función de los distintos aspectos señalados tanto en el libro Tierra adentro como en Pobladores del horizonte, podemos reconocer que ambos se asumen como algo más que simples libros de fotografía. Tanto por su formato, diagramación como por el perfil editorial de sus mentores, y especialmente por el rol otorgado a las imágenes fotográficas así como por el uso atribuido al discurso escrito, estos artefactos están en condiciones de atravesar lo que Mukarovsky denomina una "transformación artística generadora de un plus comunicacional” (Lizarazo, 2004). Este valor informacional extra se vincula en ambos casos, con la descontextualización etnográfica a la que someten a las comunidades indígenas involucradas. Al utilizar imágenes fotográficas en tales contextos editoriales se les asigna la función acrítica de ilustrar una aparente realidad. En lugar de contradecir el consenso simbólico establecido acerca del valor de la imagen fotográfica como mero reflejo-ventana al mundo, estos libros contribuyen a legitimarlo acentuando el prejuicio de que la fotografía constituye una vía de acceso directo a la realidad de las comunidades indígenas. Ese poder metonímico 
atribuido a la imagen fotográfica (la foto es parte constitutiva del retratado, es un fragmento exacto de él) se confirma en el uso que reciben en el contexto de las publicaciones. En consecuencia, no resulta relevante ni necesario aclarar e identificar cada toma a través del discurso escrito porque la imagen puede por sí misma dar cuenta de quién y en qué situación fue capturado. Este es el prejuicio que sostiene el uso de la imagen en el contexto de los libros mencionados, prejuicio que -por otra parte- no se aleja del uso convencional de la imagen en los libros de fotografía en general, no sólo etnográfica.

Por definición, el libro de fotografía (comúnmente denominado fotolibro) es el resultado del esfuerzo de un autor (fotógrafo o no) en organizar un conjunto de fotografías con la intención de elaborar una narrativa iconográfica o producir un discurso visual. Deriva de un proyecto gráfico (que determina la composición, la selección de imágenes, la impresión, la encuadernación y la narrativa fotográfica) tornándose un producto cultural de expresión singular (Fernández, en Barbosa, 2013). Por su propia concepción, es un objeto de circulación de ideas y proyectos estéticos, políticos y culturales. Es vendido, entregado, prestado, por lo tanto susceptible de llegar a distintos contextos y a un porcentaje mayor de lectores/espectadores que, por ejemplo, las exposiciones o muestras tradicionales de fotografías, que tienen un tiempo determinado de exhibición y acogen a un número reducido de personas.

Este planteo guarda cierta relación con la división de Barthes (2003 y 2009) entre obra y texto, según la cual los libros analizados son a la vez obras (artefactos en la clasificación de Mukarovsky), objetos finitos computables, fragmentos de sustancia, que ocupan una porción del espacio, se los puede tocar, manipular -sostener en la mano- y se los ve (en una biblioteca o una librería). Y a la vez -en tanto textos- (u objetos estéticos en términos de Mukarovsky) son campos metodológicos en sí mismos que no sólo muestran imágenes de comunidades indígenas, o ilustran fotográficamente distintos aspectos de su vida, sino que también y especialmente demuestran, de acuerdo a determinadas reglas convencionales, ciertas presunciones ideológicas acerca de los pueblos indígenas chaqueños. Reactualizan estereotipos culturales, refuerzan el exotismo de antaño. En este sentido están en consonancia con los libros de fotografía latinoamericana en general, cuya estructura narrativa -la construcción visual- se caracteriza por una atención al pasado nostálgico mezclado con el paisaje natural (Fernández, en Barbosa, 2013).

A su vez esta clasificación entre artefacto-objeto estético (Mukarovsky) y obra-texto (Barthes) se vincula con la realizada por Hans Belting al momento de definir la imagen. Toda imagen actúa, según el autor, como artefacto y como medio. El artefacto es la obra en imagen, la transposición de la imagen y los procedimientos con los que ella se obtiene. Sin embargo,

el qué [contenido o tema] que se busca en imágenes (...) no puede ser comprendido sin el cómo por el que se coloca como imagen o se convierte en imagen (...) es como si se leyera un enunciado tomado de un texto, en cuyo lenguaje y forma están contenidos múltiples enunciados posibles. El cómo es la comunicación genuina, la verdadera forma del lenguaje de la imagen. Sin embargo, el cómo se almacena a través de medios en los que percibimos las imágenes que nos llegan del exterior, y que sólo pueden entenderse como imágenes o relacionarse con imágenes en su medio (...) Pero se hacen visibles mediante técnicas o programas, que en retrospectiva histórica pueden llamarse medios portadores, lo mismo si aparecen en una pieza única o en pintura o en serie, como en una página impresa o en tomas fotográficas (BELTING, 2007: p. 15). 
sentido los libros analizados constituyen por un lado, los artefactos y los medios a través de los cuales se visualizan las imágenes, pero a su vez las imágenes mismas son en un plano independiente- artefacto y medio de presentificación de algunos aspectos de las comunidades retratadas, pero jamás esos aspectos mismos. Al decir de Belting "el concepto de imagen sólo puede enriquecerse si se habla de imagen y de medio como dos caras de una moneda, a las que no se puede separar, aunque estén separadas para la mirada y signifiquen cosas distintas. No basta con hablar del material para evitar el concepto de medios" (BELTING, 2007: p.16) "el medio, en primer término, nos coloca ante la posibilidad de percibir las imágenes de tal modo que no las confundimos ni con los cuerpos reales ni con las meras cosas" (BELTING, 2007: p. 17).

emargo, y tal como afirmamos anteriormente respecto de los libros analizados, a responder a procedimientos singulares de montaje y diagramación donde el vínculo imagen-palabra adopta caracteres especiales, se le confía a las imágenes su poder de comunicar-significar por sí mismas, prescindiendo de la palabra. Sin embargo, el uso de los textos que las rodean están dirigidos a controlar su polisemia, a fijar y establecer que cada imagen significa algo muy preciso. Contrariamente a lo que ocurría hace casi dos siglos atrás, cuando la fotografía suponía la mera ilustración de un texto escrito donde se encontraba en "verdad" el sentido a comunicar (la imagen hacía visible lo que se decía con palabras, era un recurso secundario que auxiliaba al texto), hoy son los textos los que asisten a las imágenes. Ordenan discursivamente lo que se muestra visualmente y pretenden condensar en pocos signos lingüísticos la densidad iconográfica de las imágenes. Si antes los textos tenían el poder de anticipar, de prever el efecto visual de las imágenes, hoy, por el contrario lo difieren, lo retrasan.

De esta forma, la tradición opone toda su fuerza de resistencia y pretende "seguir transmitiendo lo transmitido" (Gadamer, 2003) otorgando a la fotografía etnográfica chaqueña la función de visibilizar las concepciones ideológicas acerca del otro, que se elaboran y difunden discursivamente, mediante la palabra.

Por un lado entonces -y parafraseando a Rancière (2011)- la imagen fotográfica vale como potencia que desencadena la contradicción, la distancia respecto de lo consensuado tradicionalmente. Su fuerza deshace el orden convencional de los sucesos que han conformado la historia legitimada sobre el vínculo entre fotógrafos y fotografiados en el campo de los registros etnográficos. Es una peculiaridad que difiere, que concentra la desemejanza, la disconformidad, la disimilitud. Disiente, discrepa, se enfrenta y opone el acuerdo -complejo y vasto- entre los pueblos indígenas chaqueños y el sector hegemónico de la sociedad nacional.

71 Por otro lado, enlaza, vincula, articula una historia común legítima, la que se teje en la actualidad al interior de los pueblos indígenas chaqueños y desde donde opera como "puesta en comunidad". Actúa como núcleo de lo semejante, lo que define la afinidad y la proximidad. En la inestabilidad entre ambos extremos se juega su "ser" político. 


\section{BIBLIOGRAFÍA}

SAMPAIO Barbosa, ALBERTO Carlos, "Fotolivros e História Comparada da Fotografia na América Latina: Reflexões teóricas e possibilidades de investigação", in IV Encontro Nacional de Estudos da Imagem I Encontro Internacional de Estudos da Imagem. Maio de 2013, Brasil, Londrina, 2013.

Disponible en URL: http://www.uel.br/eventos/eneimagem/2013/anais2013/trabalhos/pdf/

Carlos\%20Alberto\%20Sampaio\%20Barbosa.pdf.

BARRIOS Silvia, Pobladores del horizonte, Salta, Ed. Cielo Arriba, 2010.

BARTHES Roland, El susurro del lenguaje. Más allá de la palabra y de la escritura, Barcelona, Paidós, 2009 [1987].

BARTHES Roland, Variaciones sobre la escritura, Barcelona, Paidós, 2003 [1973].

BELTING Hans, Antropología de la imagen, Buenos Aires, Ed. Katz, 2007 [2002].

GADAMER Hans Georg, Verdad y método: Fundamentos de una hermenéutica filosófica, Salamanca, Sígueme, 2003 [1977].

GIORDANO Mariana, Discurso e imagen sobre el indígena chaqueño, La Plata, Al Margen, 2008.

LIOTTA Patrick, Tierra Adentro, Pueblos originarios argentinos, Buenos Aires, Cukierman -Sánchez Editores, 2006.

LIZARAZo Diego, Iconos, figuraciones, sueños. Hermenéutica de las imágenes, México DF, Siglo XXI, 2004.

RANCIÈRE Jacques, El destino de las imágenes, Buenos Aires, Prometeo, 2011 [2009].

RICOEUR Paul, Hermenéutica y Acción. De la hermenéutica del texto a la (2008 [1985])hermenéutica de la acción. Prometeo, Buenos Aires.

\section{NOTAS}

1. La zona conocida como Chaco argentino comprende las actuales provincias de Chaco, Formosa, sur-oeste de Salta y norte de Santa Fe. Integra a su vez una amplia región situada en el centrooeste del continente sudamericano denominada Gran Chaco, que abarca además las tierras del oeste del Paraguay y el sureste de Bolivia. Esta investigación se circunscribe específicamente a la zona argentina. Por otro lado, y sin entrar en la compleja discusión terminológica acerca del alcance, pertinencia y representatividad de denominaciones como "indígena", "originario", "nativo", etc. utilizamos aquí la expresión "pueblos indígenas". Ello implica reconocer no obstante que tal denominación puede resultar problemática y poco satisfactoria en otros contextos, incluso al interior de los mismos pueblos o comunidades para quienes tampoco asume una aceptación homogénea, prefiriendo a veces la palabra "originario" o un etnónimo en su lengua vernácula.

2. Con la categoría de fotografía etnográfica aludimos en este trabajo, a las imágenes fotográficas sobre pueblos indígenas producidas por diferentes actores sociales según intereses particulares y en contextos también peculiares. Definición amplia que elaboramos en función de los propósitos de investigación y que no se circunscribe necesariamente a la fotografía producida en el marco de un estudio antropológico. Independientemente de las estrictas intenciones que suscitaron la aparición de la imagen, en adelante usaremos la expresión fotografía etnográfica para referirnos a la fotografía de pueblos indígenas en términos generales, incluso la producida en el contexto de 
los siglo XX y XXI por fotógrafos artistas, en la que si bien desaparecen las estrategias explícitas de intervención ideológica tan comunes a fines del siglo XIX y principios del XX, así como también se transforma -en parte- la concepción de registro mimético de la realidad, de "emanación perfecta del referente" (BARTHES, 2003: 137) se perciben huellas de viejos estereotipos iconográficos.

3. Plantear la hermenéutica -perspectiva tradicionalmente circunscrita al análisis de textos escritos- como metodología del análisis visual supone ampliar los límites de lo que habitualmente se entiende por textualidad (o por lenguaje, signo, discurso, palabra en tanto nociones relacionadas) para incluir a la imagen en el universo textual y concebirla como un objeto susceptible de interpretación hermenéutica. Aunque parezca paradójico es en virtud del concepto de texto que podemos articular la dimensión lingüística con la visual y vislumbrar una hermenéutica de la imagen. De allí que interrogarnos por la significación de las imágenes objeto de interés, implique admitir que ellas desbordan su literalidad y suscitan problemas de sentido que requieren ser interpretados.

4. La interpretación evocativa es una modalidad de lectura que -siguiendo a Lizarazo (2004)emerge del intercambio axiológico-simbólico entre obra e intérprete, pero sin que este último se lo proponga explícitamente. La interpretación evocativa sugiere, insinúa espontáneaindirectamente un sentido posible. La interpretación develativa por su parte, tiene lugar en el marco de una búsqueda consciente de trascender las identificaciones primarias y emerge cuando el observador concibe la imagen como objeto de interpretación profunda, cuando interroga el universo simbólico y social, el mundo estético que delimitó su producción y que "habla en ella de manera silenciosa".

5. Nacido en Houston, Texas, Patrick Patrick se mudó a la tierra natal de sus padres (Argentina) a una edad muy temprana. A los 19 años asistió a la Escuela Panamericana de Arte de Buenos Aires. Un año más tarde, se trasladó a las regiones desoladas de la Patagonia. Allí, realizó producciones fotográficas y expuso su obra por primera vez. Liotta comenzó su carrera como fotoperiodista en periódicos argentinos como La Nación y Clarín, también colaboró en Le Monde y The Times y en Los Angeles para la Associated Press. Fue corresponsal para revistas de viajes a través de las cuales visitó Asia, Oriente Medio, América Central, América del Sur y del Norte, África, el Pacífico Sur y el Caribe. Trabajó para revistas de moda, arte y publicidad como Vogue, Marie Claire, Traveler, Nombre, Luna Córnea, MAN, Geomundo, Gatopardo, etc. Vive actualmente en Los Ángeles. Información extraída de la web personal del fotógrafo : http://www.patrickliotta.com/ site.html. Consulta : 05/07/2012.

6. El libro es de tapa blanda y tiene un formato horizontal de $22 \mathrm{~cm}$ x $25 \mathrm{~cm}$. Contiene 96 páginas, 100 fotos y textos en inglés y español.

7. La gomera es una suerte de flecha utilizada para lanzar piedras y cazar animales pequeños como aves. Generalmente está formada por una horquilla de madera en forma de $Y$ de la que se desprenden dos cintas de goma atadas a las puntas superiores (de allí el nombre del elemento). La piedra que se arroja se sitúa sobre una base de cuero, tela o plástico que sostienen las cintas de goma.

8. Tanto estas imágenes como las de la zona sureña también aparecen publicadas en la web del fotógrafo, en la sección Books-images. Véase : http://www.patrickliotta.com/site.html. Consulta : 03/06/12, 18/8/12, 27/09/13.

9. Extraído de una entrevista al fotógrafo publicada en internet. Disponible en URL : $\underline{\text { http:// }}$ www.elsuplemento.com/cms/content/view/1263/44/. Consulta : 27/11/12.

10. En una entrevista el fotógrafo menciona también que Greenpeace vende los libros y las ganancias de las ventas están destinadas a la comunidad wichí de la localidad salteña de Véase : http://www.elsuplemento.com/cms/content/view/1263/44/.

11. "Patrick Liotta, un fotógrafo profesional argentino que ha vivido y registrado las costumbres de las comunidades indígenas, y Beatriz Pichi Malen, un artista indígena mapuche y galardonada 
intérprete de canciones antiguas, dieron una presentación sorprendente el martes 7 de noviembre del 2006 en Young Research Library de UCLA. En las imágenes y las leyendas vivas de su libro Proyecto Tierra Adentro, Liotta ha capturado historias de lucha y la supervivencia de la tierra de los pueblos mapuche y wichí de Argentina". Extraído de URL: http:// www.international.ucla.edu/article.asp?parentid=57901. Consulta : 25/10/12.

12. Véase : http://www.cukiermaneditores.com.ar/principal.php. Consulta : 25/10/12.

13. Extraído de http://www.elsuplemento.com/cms/content/view/1263/44/. Consulta : 22/5/13.

14. Extraído de http://www.patrickliotta.com/site.html. Consulta :22/5/13.

15. La cursiva es nuestra.

16. Rubén Romano es chaqueño. Nace en la ciudad capital de la provincia de Chaco, Resistencia, en 1961. Dedicado al estudio y la práctica fotográfica desde 1988 a partir de su participación en talleres y cursos con maestros argentinos. Expuso en Argentina, Colombia, España.

17. El libro es editado en Salta en 2010 por la Fundación Norte. Es una publicación de gran formato $(30 \times 24 \mathrm{~cm})$, de 410 páginas e incluye un DVD documental realizado bajo la dirección de Paulo Campano. Incluye textos relevados bajo la dirección de Silvia Barrios. Las fotografías son de Rubén Romano, Federico Lanusse, Argamonte, Isidoro Zang, José Luis Madrid, Riccardo Vécoli. El diseño de Keko Ferro. Contiene "Fichas etnográficas" al final de la publicación que fueron realzadas por Federico Aguilar y Raúl Cenóz. La dirección de arte pertenece a Federico Aguilar y la dirección de grabación a Héctor Gómez. Edición : Cielo Arriba. Producción General : Fundación Norte. Auspicio: Pluspetrol. Extraído de web oficial de "Argentina indígena": http:// www.argentina-indigena.org/index.php/publicaciones. Consulta : 07/4/13 y 8/06/13.

18. La fundación fue creada en 1988 con el fin de recuperar y difundir el patrimonio cultural (especialmente la música, la danza y la literatura) de las etnias indígenas del nordeste argentino. 19. Su primera actuación fue en el Teatro San Martín de Córdoba con 32 personas en escena, pertenecientes a cuatro culturas. "Participan del espectáculo los pueblos aborígenes y criollos de raíz india, que provienen del norte argentino. Está conformado por diversas manifestaciones de distintas culturas de cuatro áreas diferentes: wichí-mataco, chorote, chulupí o nivaklé; chiriguano-chané ; andina y criolla de raíz indígena. Es la intención de la dirección incorporar las expresiones de las restantes culturas aborígenes del país. Todos sus integrantes son legítimos portadores de un arte vivo (a veces escondido) en la tradición oral de sus pueblos. Frecuentemente se rota a sus integrantes, para posibilitar la participación de la mayor cantidad de músicos en la trascendente experiencia del escenario (...) Todos los participantes, fuera de la época de conciertos, vuelven a sus formas tradicionales de vida como pescadores, cazadores, recolectores, artesanos u obreros, en las comunidades indígenas, en los pequeños pueblos o en las villas suburbanas de las ciudades (...) Han participado hasta ahora de este espectáculo alrededor de doscientos cincuenta músicos, cantores y bailarines de las diferentes culturas, abarcando desde recitales solistas de Silvia Barrios (también llamados Cantos del origen) hasta presentaciones conjuntas de más de setenta personas. Extraído de la web oficial: http://www.argentinaindigena.org/. Consulta : 22/5/13.

20. De esta producción particular, hay veinte imágenes en la página web del fotógrafo : http:// rubenromano.com/galeria.php?numero=200. Consulta : 22/5/13.

21. El epílogo del libro se centra en las imágenes de los diferentes viajes que realizó el grupo/ espectáculo Argentina indígena por distintas ciudades del mundo (Berlín, Frankfurt, Hannover, Munich, Mainz, Bremen, Bielefeld, París, Argelia, etc.).

22. En lo que sigue iremos describiendo cada uno de estos capítulos, deteniéndonos particularmente en aquellos cuyas imágenes despierten especialmente nuestro interés y nos lleven a interrogarlas para explicar el porqué de su singularidad. Cabe aclarar que el detalle descriptivo que desarrollamos es relevante y pertinente al análisis del uso de imágenes fotográficas en el contexto editorial de una publicación. Es a partir de dicha instancia en la que se detalla y enumera de manera pormenorizada lo visto en cada imagen que podemos luego hallar 
elementos comunes y recurrentes en toda la publicación y elaborar a partir de allí reflexiones que trasciendan la simple visualización homogénea y uniforme. Dicho en términos de Lizarazo (2004), es importante atravesar esta primera instancia material-icónica fundada en la simple enumeración o nomenclatura tipográfica, para acceder a partir de allí a la dimensión inmaterial que no obstante se encarna en la textura de la imagen e involucra a la tradición, la historia cultural y los mundos sociales, sus interconexiones, dependencias y entrecruzamientos. De modo que el sentido visual a construir puede en cierto punto ser identificable a través de lo que cada imagen muestra de manera individual y en el conjunto del libro. No se trata no obstante de una mera acumulación y sumatoria de datos a partir de la cual extraer conclusiones generales, sino de una multiplicidad de relaciones posibles que se despliegan en torno a cada imagen y se aproximan a otros de manera siempre parcial y transitoria.

\section{RESÚMENES}

El artículo analiza -en clave hermenéutica- el uso de la fotografía etnográfica de la región argentina del Gran Chaco en los libros Tierra Adentro (2006) y Pobladores del horizonte. Pueblos wichí y chorote hoy (2010). Nuestra hipótesis sostiene que la incorporación de la fotografía etnográfica en el contexto editorial de estas publicaciones abre un espacio de disenso (Rancière, 2011) respecto de los usos y sentidos tradicionales. Las imágenes dejan entrever una participación activa de los retratados en la instancia de captura, y de este modo se alejan de viejos estereotipos de representación. No obstante, las relaciones entre las imágenes y los textos que las acompañan en las publicaciones, reactualiza el exotismo de antaño.

A partir d'une approche herméneutique, l'article analyse l'utilisation de la photographie portant sur la région argentine du Grand Chaco dans les livres Tierra Adentro (2006) et Pobladores del horizonte. Pueblos wichí y chorote hoy (2010). Notre hypothèse soutient que l'insertion de la photographie ethnographique dans le domaine éditorial de ces publications déclenche un débat (Rancière, 2011) par rapport à son utilisation et à son sens traditionnels. Les images laissent entrevoir une participation active de ceux qui sont photographiés au moment de la prise de vue, s'éloignant ainsi de vieux stéréotypes de représentation. Cependant, les rapports entre les images et les textes qui les accompagnent dans les publications réactualisent l'exotisme d'antan.

\section{ÍNDICE}

Mots-clés: photographie, indigène, Gran Chaco, livre, herméneutique, exotisme

Palabras claves: fotografía, indígena, Gran Chaco, libro, hermenéutica, exotismo

\section{AUTOR}

\section{ALEJANDRA REYERO}

Doctora en Artes por la Universidad Nacional de Córdoba (Argentina). Investigadora Asistente del Consejo Nacional de Investigaciones Científicas y Técnicas (CONICET). Miembro del Núcleo de Estudios y Documentación de la Imagen (NEDIM) del Instituto de Investigaciones Geohistóricas - 
CONICET/UNNE. Docente en la Licenciatura en Artes Combinadas de la Facultad de Artes, Diseño y Ciencias de la Cultura (FADyCC-UNNE). 